\title{
Coulisses
}

Revue de théâtre

5 | Hiver 1992

Varia

\section{Poèmes inédits}

\section{Pierre Perrin}

\section{OpenEdition}

Journals

Édition électronique

URL : http://journals.openedition.org/coulisses/1730

DOI : $10.4000 /$ coulisses. 1730

ISSN : 2546-9460

\section{Éditeur}

Presses universitaires de Franche-Comté

\section{Édition imprimée}

Date de publication : 1 janvier 1992

Pagination : 70

ISSN : 1150-594X

\section{Référence électronique}

Pierre Perrin, «Poèmes inédits », Coulisses [En ligne], 5 | Hiver 1992, mis en ligne le 04 juillet 2017, consulté le 23 octobre 2019. URL : http://journals.openedition.org/coulisses/1730 ; DOI : 10.4000/ coulisses. 1730

Ce document a été généré automatiquement le 23 octobre 2019

Coulisses 


\title{
Poèmes inédits
}

\author{
Pierre Perrin
}

\section{L'âge d'argent}

1 À la fin du vingtième siècle, l'éphémère a supplanté l'éternité. La poudre aux yeux a raison de tout. Il faut être aveugle, et ne pas le reconnaître. Vivre en superficie, mettre en commun la pensée et niveler des abîmes, telle est la réalité de l'Occident. Sur tout: se taire, à grands cris.

L'échappatoire, c'est la réussite. Voilà le mot d'ogre, le hochet à décrocher sous la canicule des médias. Le prix d'une telle hystérie: un écrasement individuel. Sont rejetés ou, en tout cas, laminés l'amour, la passion, le partage. Chacun se rue d'enthousiasme dans le vide.

On rétracte le regard jusque dans le nombril. Un sourire n'ouvre plus le monde. La parole est une affaire, et rien d'autre. Qui refuse un tel monopole est bientôt rayé de la civilisation. Et le plus grand poète français vivant en est réduit à vivre comme un clochard.

Est-ce que la jeunesse, un jour, s'insurgera contre une telle inhumanité ? Qui lui prêtera des valeurs neuves? Mon écœurement est inutile, que nul ne reprend à son compte. Au moins je mourrai debout, peut-être, sur mon poème en barricade.

\section{Ballade à N.D. la Mort}

2 Madame, à l'heure du destin, ne tergiversez pas : entrez. N'ayez aucun souci du feu dans la cheminée. Vous pourrez fermer la porte, ou la laisser battante. Faites votre œuvre.

La mienne restera sans doute inachevée, si elle survit à mon corps emporté. J'aurai misé tant de chimères sur l'avenir. Madame, entre vos bras, je n'aurai plus besoin de rien, amour compris.

Madame, tant de jours je vous aurai cherchée. Vos doigts m'auront souvent apaisé, sur les lèvres: et vos coudes serrés comme on porte au-dessus de sa tête, en forêt, un 
enfant qui pleure de rire.

Mais quelqu'un, madame, risque de vous barrer la route, tellement m'adore ma compagne du second souffle; s'il vous plaît, laissez la vivre. Hors d'elle, rien pour moi n'a d'importance.

Madame, j'ai cessé de trembler à votre nom. Mon fils est élevé. Le bonheur m'appartient. Pourtant, si nous faisions la paix ! Si vous nous épargniez, mon amour et moi, encore vingt ou trente années... 